ISLAMIC BANKING: Jurnal Pemikiran dan Pengembangan Perbankan Syariah, Volume 6 Nomor 2 Edisi Februari 2021

\title{
ANALISIS PENINGKATAN KESEJAHTERAAN NASABAH TERHADAP PEMBIAYAAN MURABAHAH (STUDI KASUS BANK ACEH SYARIAH CAPEM KRUENG GEUKUEH)
}

\author{
Maulida Mahdalena \\ Mahasiswa Fakultas Ekonomi dan Bisnis IAIN Lhokseumawe \\ Email: maulidamahdalena02@gmail.com \\ Suryani \\ Fakultas Ekonomi dan Bisnis IAIN Lhokseumawe \\ Email: suryapijar@yahoo.com \\ Ismaulina \\ Fakultas Ekonomi dan Bisnis IAIN Lhokseumawe \\ Email: ismaulina@gmail.com
}

\begin{abstract}
This study aims to determine differences in income before and after getting murabaha financing at Bank Aceh Syariah Capem Krueng Geukueh. The research method uses quantitative methods with a sample of 45 respondents. Data collection was carried out using a Likert scale questionnaire. Based on the results of the study there is a relationship between welfare and cheap financing at Bank Aceh Syariah Capem Krueng Geukeuh, with the difference in the difference in average income before and after amounting to -8,587 to -7,635. This research is useful for researchers themselves, for banks, for murabaha financing customers, and for future researchers.
\end{abstract}

Keywords: Leadership, Work Discipline, Employee Performance, Islamic Banking

\begin{abstract}
Abstrak
Penelitian ini bertujuan untuk mengetahui perbedaan pendapatan sebelum dan sesudah mendapatkan pembiayaan murabahah di Bank Aceh Syariah Capem Krueng Geukueh. Metode penelitian menggunakan metode kuantitatif dengan sampel sebanyak 45 responden. Pengumpulan data dilakukan dengan menggunakan kuesioner skala Likert. Berdasarkan hasil penelitian terdapat hubungan antara kesejahteraan dan pembiayaan murah pada Bank Aceh Syariah Capem Krueng Geukeuh, dengan perbedaan selisih pendapatan rata-rata sebelum dan sesudah sebesar -8.587 sampai -7.635. Penelitian ini bermanfaat bagi para peneliti itu sendiri, bagi bank, bagi pelanggan pembiayaan murabahah, dan bagi peneliti masa depan.
\end{abstract}

Kata Kunci: $\quad$ Kepemimpinan, Disiplin Kerja, Kinerja Karyawan, Perbankan Syariah 


\section{Dasar Pemikiran}

Perbankan syariah di Indonesia mulai berdiri tahun 1992, dengan salah satu motifnya antara lain adalah membangun ekonomi umat Islam, di Indonesia lembaga keuangan dibagi menjadi dua yakni lembaga keuangan dengan prinsip ekonomi konvensional dan lembaga keuangan dengan prinsip ekonomi syariah. Perkembangan Lembaga Keuangan Syariah (LKS) di Indonesia cukup baik, hal ini terlihat pada aset yang dimiliki oleh lembaga keuangan syariah yakni bank syariah, meningkat dari tahun ketahun. Masyarakat beranggapan bahwa bank syariah itu hanya untuk orang Islam dan merupakan Bank sosial, namun pada kenyataan bank syariah itu umumnya bank komersial, melayani siapa saja dan dilaksanakan oleh siapa saja, baik muslim maupun non muslim (Hakim, 2011: 59).

Perbankan syariah memliki banyak produk-produk yang di aplikasikan, salah satunya pembiayaan murabahah. Produk murabahah merupakan produk yang banyak diminati oleh masyarakat karena pembiayaan murabahah adalah jual beli dengan menyatakan harga perolehan dan keuntungannya (margin) sesuai yang disepakati oleh penjual dan pembeli. Pembayaran atas akad jual beli murabahah dapat dilakukan secara tunai maupun kredit, hal inilah yang membedakan murabahah dengan jual beli lainnya yaitu penjual harus memberitahukan harga barang pokok yang akan dijual serta jumlah keuntungan yang diperoleh (Suriani, 2018: 6).

Sesuai akad pembiayaan murabahah yang diterapkan di Bank Aceh Syariah hanya diberikan untuk usaha yang halal dan sesuai syariah Islam. Selain itu, pembiayaan murabahah juga memiliki tujuan yaitu membantu perekonomian dan meningkatkan kesejahteraan nasabah serta berusaha mengembalikan lagi sistem Islam dalam setiap transaksi muamalah yang jauh dari bunga dan riba. Pembiayaan murabahah merupakan salah satu segmen bisnis di Bank Aceh Syariah yang memiliki variasi produk agar dapat membantu nasabah untuk memenuhi kebutuhannya, sehingga pembiayaan ini dapat menyelesaikan persoalan nasabah dalam hal permodalan dengan adanya akses modal dari perbankan, pelaku usaha keluar dari gerbang kesulitan dalam upaya peningkatan aktivitas produksi, sehingga seseorang dapat meningkatkan kesejahteraan hidupnya. 
Dampak dari pembiayaan murabahah itu sendiri bisa kita lihat dengan adanya peningkatan pendapatan dan peningkatan keuntungan usahanya tersebut. Peningkatan terhadap pendapatan nasabah ini bisa terjadi dengan adanya penambahan modal yang berupa bantuan modal dan penambahan penjualan barang-barang yang dijual.

Meningkatkan kesejahteraan nasabah dan menyalurkan modal untuk usaha merupakan tujuan dari adanya program pembiayaan yang dilakukan oleh Bank Aceh Syariah, adapun pengertian kesejahteraan merupakan sejumlah kepuasan yang diperoleh seseorang dari hasil mengkonsumsi pendapatan yang diterima. Namun demikian tingkatan dari kesejahteraan itu sendiri merupakan sesuatu yang bersifat relatif karena tergantung dari besarnya kepuasan yang diperoleh dari hasil mengkonsumsi pendapatan tersebut (https://sinta.unud.ac.id, di akses 06 agustus 2019). Adapun menurut Kolle (dalam Bintarto 1989) kesejahteraan dapat diukur dari beberapa aspek kehidupan, yaitu pendapatan, pendidikan, kesehatan, keluarga berencana, pola konsumsi, ketenagakerjaan, dan perumahan.

Berdasarkan latar belakang masalah diatas, maka perumusan masalah penelitian ini adalah Bagaimana perbedaan pendapatan sebelum dan setelah mendapatkan pembiayaan murabahah pada Bank Aceh Syariah Capem Krueng Geukueh?, dengan tujuan untuk mengetahui perbedaan pendapatan sebelum dan sesudah mendapatkan pembiayaan murabahah pada Bank Aceh Syariah Capem Krueng Geukueh.

\section{Landasan Teori}

\section{Teori Kesejahteraan}

Kesejahteraan sosial adalah sekelompok manusia yang telah memiliki tatanan hidup dimana dalam kehidupannya telah terpenuhi segala bentuk kebutuhan hidup khususnya makan, pakaian, pendidikan, dan kesehatan atau terpenuhinya kebutuhan-kebutuhan jasmaniah, rohaniah, dan sosial, sedangkan tujuan kesejahteraan sosial adalah untuk menjamin kebutuhan ekonomi manusia, standar kesehatan, dan kondisi kehidupan yang layak (Haq dan Kalamika, t.th: 260). 
Konsep kesejahteraan menurut Nasikun dapat dirumuskan sebagai padanan makna dari konsep martabat manusia yang dapat dilihat dari empaat indikator yaitu rasa aman, kesejahteraan, kebebasan, jati diri (Nasikun, 1993). Menurut Kolle dalam Bintarto, kesejahteraan dapat diukur dari beberapa aspek kehidupan antara lain: (Rosni, 2019: $57)$

a. Dengan melihat kualitas hidup dari segi materi, seperti kualitas rumah, bahan pangan dan sebagianya

b. Dengan melihat kualitas hidup dari segi fisik, seperti kesehatan tubuh, lingkungan alam, dan sebagainya Dengan melihat kualitas hidup dari segi mental, seperti fasilitas pendidikan, lingkungan budaya, dan sebagainya

c. Dengan melihat kualitas hidup dari segi spiritual, seperti moral, etika, keserasian penyesuaian, dan sebagainya.

d. Dengan melihat kualitas hidup dari segi mental seperti fasilitas pendidikan, lingkungan budaya, dan sebagainya.

\section{Pendapatan}

Pendapatan adalah semua penghasilan yang didapat oleh keluarga baik berupa uang ataupun jasa. Setiap orang berhak untuk bekerja untuk memperoleh pendapatan, apabila pendapatan tersebut dapat memenuhi kebutuhan sehari-hari dan mencukupi kebutuhan rumah tangga lainnya maka keluarga tersebut dikatakan makmur, untuk masyarakat yang berpenghasilan kecil mereka berupaya hasil dari pekerjaannya hanya untuk memenuhi kebutuhan sehari-hari. Keluarga yang berpenghasilan menengah mereka lebih terarah kepada pemenuhan kebutuhan pokok yang layak seperti makan, pakaian, perumahan, pendidikan dan lain-lain. Keluarga yang berpenghasilan tinggi dan berkecukupan maka mereka akan memenuhi segala keinginan yang mereka inginkan (Ridwan dalam http://www.ridwan-belitung.blogspot.com).

Secara garis besar pendapatan digolongkan menjadi tiga golongan, yaitu: (Suparmoko, 1991: 35) 
a. Gaji dan Upah. Imbalan yang diperoleh setelah orang tersebut melakukan pekerjaan untuk orang lain yang diberikan dalam waktu satu hari, satu minggu maupun satu bulan.

b. Pendapatan dari Usaha Sendiri. Merupakan nilai total dari hasil produksi yang dikurangi dengan biaya-biaya yang dibayar dan usaha ini merupakan usaha milik sendiri atau keluarga dan tenaga kerja berasal dari anggota keluarga sendiri, nilai sewa kapital milik sendiri dan semua biaya ini biasanya tidak diperhitungkan.

c. Pendapatan dari Usaha Lain. Pendapatan yang diperoleh tanpa mencurahkan tenaga kerja, dan ini biasanya merupakan pendapatan sampingan antara lain pendapatan dari hasil menyewakan aset, ternak dan barang lain, bunga dan uang, sumbangan, pendapatan pensiun, dan lain-lain.

\section{Teori Pembiayaan}

Pembiayaan juga merupakan pendanaan yang diberikan oleh suatu pihak kepada pihak lain untuk mendukung investasi yang telah direncanakan baik yang dikeluarkan untuk mendukung investasi yang direncanakan, sedangkan pembiayaan dengan prinsip syariah adalah penyediaan uang/tagihan yang dipersamakan dengan itu berdasarkan persetujuan/kesepakatan antara bank dengan pihak lain yang mewajibkan pihak yang di biayai dengan imbalan atau bagi hasil. Adapun yang menjadi perbedaan antara kredit yang diberikan oleh bank berdasarkan konvensional dengan pembiayaan yang diberikan oleh bank berdasarkan prinsip syariah adalah terletak pada keuntungan yang diharapkan, bagi bank berdasarkan prinsip konvensional, keuntungan diperoleh melalui bunga. Sedangkan bagi bank berdasarkan prinsi syariah berupa imbalan/bagi hasil. Perbedaan lainnya terdiri dari analisis pemberian pembiayaan (kredit) beserta persyaratannya (Kasmir, 2012: 72-73).

Secara umum tujuan pembiayaan dibedakan menjadi dua kelompok, yaitu tujuan pembiayaan untuk tingkat makro dan tujuan pembiayaan untuk tingkat mikro. Secara makro pembiayaan bertujuan (Aisyah, 2014: 4): 
a. Peningkatan ekonomi umat, artinya masyarakat yang tidak dapat akses secara ekonomi, dengan adanya pembiayaan mereka dapat melakukan akses ekonomi.

b. Tersedianya dana bagi peningkatan usaha, artinya untuk setiap pengembangan usaha membutuhkan dana tambahan, dana tambahan ini dapat diperoleh melalui pembiayaan.

c. Meningkatkan produktivitas, artinya adanya pembiayaan memberikan peluang bagi masyarakat agar mampu meningkatkan daya produksinya.

d. Membuka lapangan kerja baru, artinya dengan dibukanya sektor- sektor usaha melalui penambahan dana pembiayaan, maka sektor usaha tersebut akan menyerap tenaga kerja.

e. Terjadinya distribusi pendapatan, artinya masyarakat usaha produktif mampu melakukan aktivitas kerja, berarti mereka akan memperoleh pendapatan dari hasil usahanya.

Adapun fungsi pembiayaan dapat dijelaskan sebagain berikut yaitu:

1) Meningkatkan daya guna uang, para penabung menyimpan uangnya dalam bentuk giro, tabungan, dan deposito. Uang tersebut dalam presentase tertentu ditingkatkan kegunaannya oleh lembaga keuangan guna suatu usaha peningkatan produktivitas. Para pengusaha menikmati pembiayaan dari lembaga keuangan untuk memperluas dan memperbesar usahanya baik untuk peningkatan produksi, perdagangan, maupun usaha lainnya.

2) Meningkatkan daya guna barang, produsen dengan bantuan lembaga keuangan dapat mengubah bahan mentah menjadi bahan jadi sehingga daya guna barang tersebut bertambah nilainya. Produsen dengan bantuan pembiayaan dapat memindahkan barang dari satu tempat yang kegunaannya kurang ke tempat yang lebih bermanfaat.

3) Meningkatkan peredaran uang, melalui pembiayaan, peredaran uang kartal maupun giral akan lebih berkembang karena pembiayaan menciptakan suatu kegairahan berusaha sehingga penggunaan uang akan bertambah baik secara kualitatif maupun kuantitatif.

4) Menimbulkan kegairahan baru berusaha, kegiatan usaha sesuai dengan dinamikanya akan selalu meningkat, akan tetapi peningkatan usaha tidaklah selalu diimbangi 
ISLAMIC BANKING: Jurnal Pemikiran dan Pengembangan Perbankan Syariah, Volume 6 Nomor 2 Edisi Februari 2021

dengan peningkatan kemampuannya dalam bentuk modal, oleh karena itu bantuan pembiayaan yang diterima pengusaha dari lembaga keuangan dapat digunakan untuk memperbesar volume usaha dan produktivitasnya.

5) Stabilitas ekonomi, dalam ekonomi yang kurang sehat, langkah-langkah stabilisasi pada dasarnya diarahkan pada usaha-usaha untuk antara lain: pengendalian inflasi, peningkatan ekspor, rehabilitasi prasarana, pemenuhan kebutuhan-kebutuhan pokok rakyat. Menekan arus inflasi dan terlebih-lebih lagi untuk usaha pembangunan ekonomi maka pembiayaan lembaga keuangan memegang peranan yang penting.

6) Sebagai jembatan untuk meningkatkan pendapatan nasional, para usahawan memperoleh pembiayaan untuk meningkatkan usahanya. Peningkatan usaha berarti peningkatan profit.

\section{Teori Murabahah}

Murabahah adalah akad jual beli antara dua belah pihak, dimana pembeli dan penjual menyepakati harga jual, yang terdiri atas harga beli ditambah ongkos pembelian dan keuntungan bagi penjual. Pemahaman lain murabahah adalah akad jual beli barang dengan menyatakan harga perolehan dan keuntungan (margin) yang disepakati oleh penjual dan pembeli. Murabahah dapat dilakukan secara tunai, bisa juga secara bayar tangguh atau bayar dengan angsuran, pemahaman lain Murabahah adalah transaksi jual beli, dimana bank mendapat sejumlah keuntungan. Dalam hal ini, bank menjadi penjual dan nasabah menjadi pembeli (Sutedi, 2009: 95).

Murabahah dalam teknis perbankan adalah akad jual beli antara bank selaku penyedia bank dengan nasabah yang memesan untuk membeli barang. Adapun rkun dan syaratnya adalah sebagai berikut:

a. Rukun Murabahah:

1) Pelaku akad, yaitu (penjual) adalah pihak yang memiliki barang untuk dijual, dan (pembeli) adalah pihak yang memerlukan dan akan membeli barang.

2) Objek akad, yaitu mabi' (Barang dagangan) dan tsaman (harga).

3) Shigat, yaitu Ijab-qabul (Askara, 2007: 82). 
b. Adapun Syarat-syarat dari murabahah adalah:

1) Penjual memberitahu biaya modal kepada nasabah

2) Kontrak pertama harus sah sesuai dengan rukun yang ditetapkan.

3) Kontrak harus bebas dari riba.

4) Penjual harus menjelaskan setiap cacat yang terjadi sesudah pembelian dan harus membuka semua hal yang berhubungan dengan cacat.

5) Penjual harus menyampaikan semua hal yang berkaitan dengan pembelian, misalnya jika pembelian dilakukan secara utang (Sutedi, 2009: 122).

\section{Kerangka Konseptual}

Kerangka berpikir atau juga disebut sebagai kerangka konseptual merupakan model konseptual tentang bagaimana teori berhubungan dengan berbagai faktor yang telah teridentifikasi sebagai masalah yang penting. Deskripsi teori dan hasil penelitian terdahulu merupakan landasan utama untuk menyusun kerangka berpikir yang pada akhirnya digunakan dalam merumuskan hipotesis (Zainuddin, 2011: 199). Adapun yang menjadi kerangka teori dalam penelitian ini adalah:

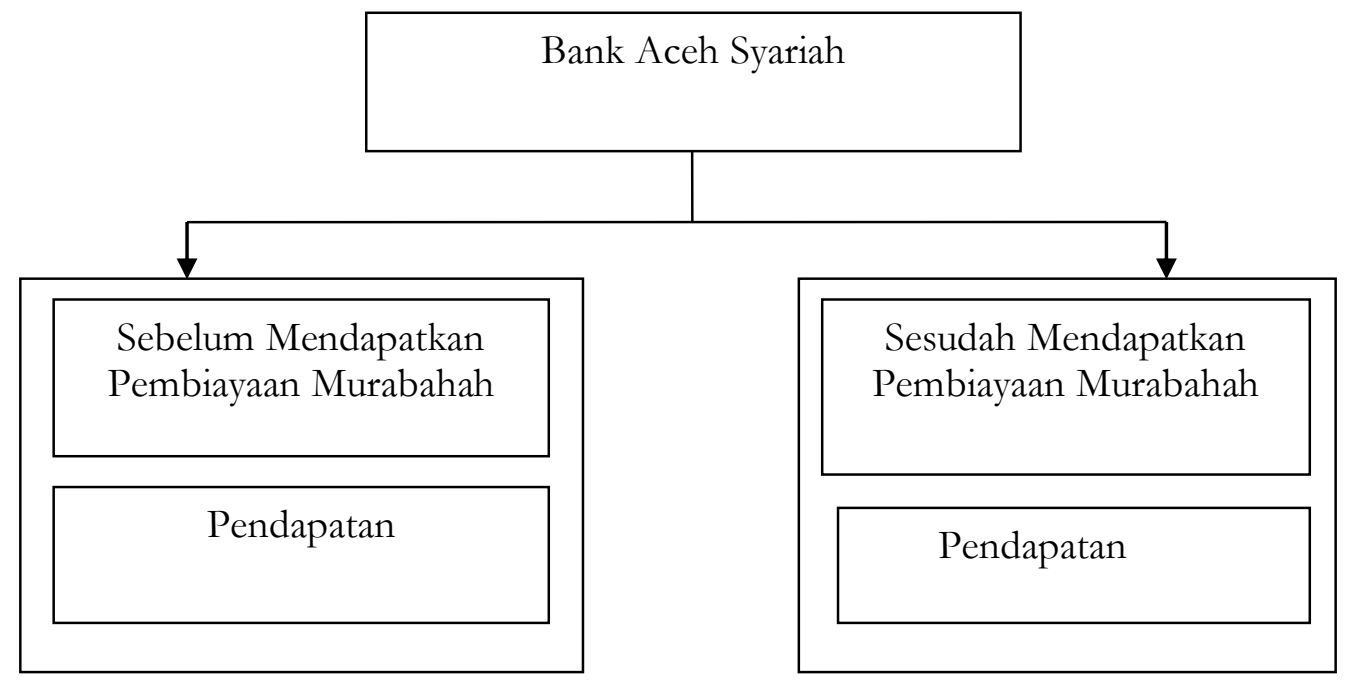

Gambar 2.1 Kerangka Teori

\section{Hipotesis}

Berdasarkan dari uraian di atas maka untuk penelitian ini diajukan hipotesis sebagai berikut: 
ISLAMIC BANKING: Jurnal Pemikiran dan Pengembangan Perbankan Syariah, Volume 6 Nomor 2 Edisi Februari 2021

$\mathrm{HO}_{1}$ : Tidak terdapat perbedaan pendapatan sebelum dan sesudah mendapatkan pembiayaan murabahah pada Bank Aceh Syariah Capem Krueng Geukueh

$\mathrm{Ha}_{1}$ : Terdapat perbedaan pendapatan sebelum dan sesudah mendapatkan pembiayaan murabahah pada Bank Aceh Syariah Capem Krueng Geukueh

\section{Metode Penelitian}

Pendekatan penelitian yang peniliti gunakan yaitu pendekatan penelitian kuantitatif. Penelitian dengan pendekatan kuantitatif sangat terkait dengan analiss data yang berbentuk numerik/angka. Pendekatan yang didasari pada penggambaran data berbasis angka seperti tingkat persentasi tingkat penggangguran, kemiskinan dan lain-lain (Suryani dan Hendryadi, 2018: 109)

Populasi dapat didefiniskan sebagai keseluruhan kelompok orang, kejadian atau hal minat yang ingin peneliti investigasikan (Sekaran, 2006: 121). Populasi dalam penelitian ini adalah seluruh nasabah yang mengambil produk pembiayaan murabahah. Sampel adalah sebagian atau wakil yang diteliti adapun (Arikunto, 2006: 131). Adapun sample yang diambil sebanyak 45 orang yang (Data Populasi Tersebut Diperoleh Dari Hasil Wawancara Dengan Salah Satu Karyawan Bank Aceh Syariah Capem Krueng Geukueh, Yaitu Bapak Nanta Aulia, pada tanggal 9 Desember 2019). Dalam pengumpulan data peneliti menggunakan dengan cara dokumentasi, wawancara, dan kuisioner.

\section{Hasil Penelitian}

Adapun hasil dari uji validitas pada penelitian ini menggunakan SPSS versi 23 antara lain sebagai berikut:

a. Uji Validitas

Tabel 4.1

Hasil Pengujian Validitas

\begin{tabular}{|c|c|c|c|c|}
\hline Variabel & $\begin{array}{c}\text { Item } \\
\text { Pertanyaan }\end{array}$ & $\mathbf{R}_{\text {hitung }}$ & $\mathbf{R}_{\text {tabel }}$ & Keterangan \\
\hline Pendapatan & 1 & 0.460 & 0.2940 & Valid \\
\cline { 2 - 5 } Sebelum (X) & 2 & 0.592 & 0.2940 & Valid \\
\hline Pendapatan & 1 & 0.306 & 0.2940 & Valid \\
\hline
\end{tabular}




\begin{tabular}{|c|c|c|c|c|}
\hline Setelah (X) & 2 & 0.367 & 0.2940 & Valid \\
\hline $\begin{array}{c}\text { Pembiayaan } \\
\text { Murabahah (Y) }\end{array}$ & 1 & 0.323 & 0.2940 & Valid \\
\hline
\end{tabular}

Sumber: Hasil Penelitian (Hasil Olahan SPSS), 2020

Berdasarkan tabel 4.1 diatas terlihat bahwa semua nilai $\mathrm{R}_{\text {hitung }}$ lebih besar dari pada $\mathrm{R}_{\text {tabel }}$ yaitu sebesar 0.2940 , sehingga semua pertanyaan telah valid.

b. Uji Reabilitas

\section{Pendapatan Sebelum}

Tabel 4.2

Hasil Pengujian Cronbach's Alpha

Reliability Statistics

\begin{tabular}{|r|r|}
\hline Cronbach's Alpha & N of Items \\
\hline, 615 & 6 \\
\hline
\end{tabular}

\section{Pendapatan Setelah}

\section{Reliability Statistics}

\begin{tabular}{|r|c|}
\hline Cronbach's Alpha & N of Items \\
\hline, 510 & \\
\hline
\end{tabular}

Sumber: Hasil Penelitian (Hasil Olahan SPSS), 2020

Pembiayaan Murabahah

Reliability Statistics

\begin{tabular}{|r|r|}
\hline Cronbach's Alpha & N of Items \\
\hline & \\
& \\
\hline
\end{tabular}

Sumber: Hasil Penelitian (Hasil Olahan SPSS), 2020

Berdasarkan hasil pengujian reliabilitas pada tabel di atas, dapat dilihat bahwa hasil pengujian instrumen penelitian dari segi reliabilitas item-total statistics terhadap 45 responden menunjukkan semua item pertanyaan untuk variabel-variabel independen yaitu Pendapatan Sebelum (X) mempunyai nilai Cronbach's Alpha 0.615 yang melewati batas minimal 0,40, Pendapatan Setelah (X) mempunyai nilai Cronbach's Alpha 0.510 yang melewati batas minimal 0,40 , dan variabel dependen yaitu Pembiayaan Murabahah (Y) mempunyai nilai Cronbach's Alpha 0.469 yang melewati 
batas minimal 0,40. Maka dengan demikian dapat disimpulkan bahwa semua item pertanyaan pada kuesioner dianggap reliabel.

Adapun hasil uji asumsi klasik pada penelitian ini menggunakan SPSS versi 23 yaitu sebagai berikut:

a. Uji Normalitas

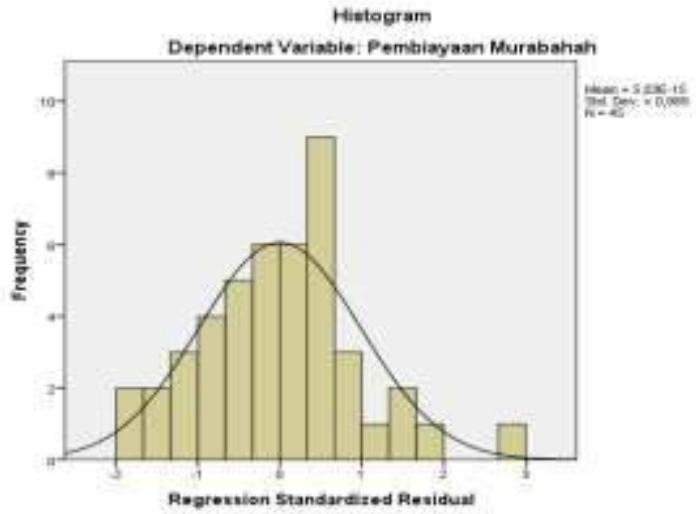

Tabel 4.2

Uji Normalitas Kolmogorov-Smirnov

One-Sample Kolmogorov-Smirnov Test

\begin{tabular}{|ll|r|}
\hline & & $\begin{array}{r}\text { Unstandardiz } \\
\text { ed Residual }\end{array}$ \\
\hline N & Mean & 45 \\
& Std. &, 0000000 \\
& Deviation &, 81968332 \\
Most Extreme & Absolute &, 093 \\
Differences & Positive &, 093 \\
& Negative &,- 063 \\
Test Statistic & &, 093 \\
Asymp. Sig. (2-tailed) & &, $200^{\mathrm{c}, \mathrm{d}}$ \\
\hline
\end{tabular}

a. Test distribution is Normal.

b. Calculated from data.

c. Lilliefors Significance Correction.

$\mathrm{d}$. This is a lower bound of the true significance.

Sumber: Hasil Penelitian (Hasil Olahan SPSS), 2020 
Dari grafik atau histogram terlihat bahwa residual terdistribusi secara normal. Untuk lebih memastikan residual data telah mengikuti asumsi normalitas, maka residual data diuji kembali dengan menggunakan uji Kolmogrov Smirnov.

Berdasarkan tabel 4.2 diatas pada uji Kolmogrov Smirnov menunjukkan bahwa nilai Asymp.Sig sebesar 0.200. Nilai sig $(0.200)>(0.05)$ sehingga dapat disimpulkan bahwa data normal dan terpenuhi uji normalitas.

b. Uji Autokorelasi

Tabel 4.3

Hasil Uji Autokorelasi

\begin{tabular}{|l|c|r|c|c|c|}
\hline Model Summary \\
\hline Model & R & R Square & $\begin{array}{c}\text { Adjusted R } \\
\text { Square }\end{array}$ & $\begin{array}{c}\text { Std. Error of } \\
\text { the Estimate }\end{array}$ & $\begin{array}{c}\text { Durbin- } \\
\text { Watson }\end{array}$ \\
\hline 1 &, $400^{\mathrm{a}}$ &, 160 &, 141 &, 829 & 2,222 \\
\hline
\end{tabular}

a. Predictors: (Constant), Pendapatan

b. Dependent Variable: Pembiayaan Murabahah

Sumber: Hasil Penelitian (Hasil Olahan SPSS), 2020

Berdasarkan tabel diatas nilai DW sebesar 2,222 dengan jumlah sampel 45 (n) dan jumlah variabel independen $1(\mathrm{~K}=1)$, maka nilai $\mathrm{du}=1,5660$ dan nilai 4-du $=2,434 \mathrm{Jadi}$ nilai $\mathrm{du}<\mathrm{d}<4$-du $(1,5660<2,222<2,434)$, maka dapat disimpulkan tidak terdapat autokorelasi pada regresi ini.

c. Uji Multikolinearitas

Tabel 4.4

Hasil Uji Multikolinearitas

Coefficients $^{\mathrm{a}}$

\begin{tabular}{|c|c|c|c|c|c|c|c|c|}
\hline \multirow{2}{*}{\multicolumn{2}{|c|}{ Model }} & \multicolumn{2}{|c|}{$\begin{array}{l}\text { Unstandardized } \\
\text { Coefficients }\end{array}$} & \multirow{2}{*}{$\begin{array}{c}\text { Standardized } \\
\text { Coefficients }\end{array}$} & \multirow{2}{*}{$t$} & \multirow[b]{2}{*}{ Sig. } & \multicolumn{2}{|c|}{$\begin{array}{c}\text { Collinearity } \\
\text { Statistics }\end{array}$} \\
\hline & & $\mathrm{B}$ & Std. Error & & & & Tolerance & VIF \\
\hline & (Constant) & 32,293 & 3,178 & & 10,162 & ,000 & & \\
\hline & Pendapatan &,- 239 & ,083 &,- 400 & $-2,863$ & ,006 & 1,000 & 1,000 \\
\hline
\end{tabular}

a. Dependent Variable: Pembiayaan Murabahah

Sumbe : Hasil Penelitian (Hasil Olahan SPSS), 2020

Berdasarkan tabel 4.4 diatas, maka dapat diketahui nilai VIF untuk masing-masing variabel penelitian sebagai berikut nilai VIF pendapatan sebesar 1,000 $<10$ dan nilai 
toleransi $1,000>0,10$ sehingga variabel pendapatan dinyatakan tidak terjadi multikolinearitas.

d. Uji Heteroskedastisitas

Tabel 4.5

Hasil Uji Heteroskedastisitas

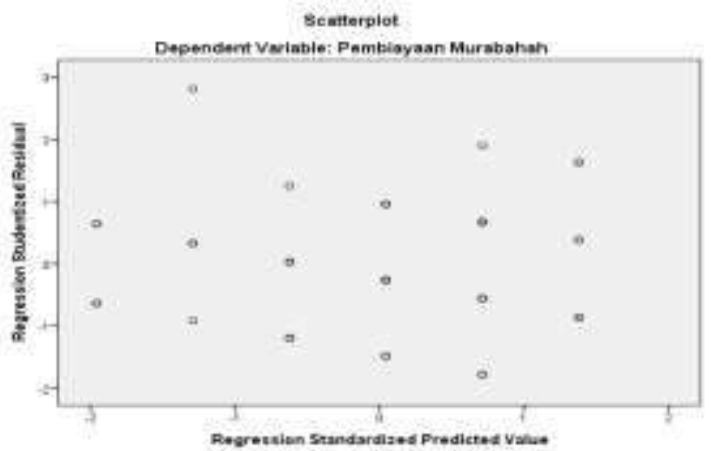

Sumber: Hasil Penelitian (Hasil Olahan SPSS), 2020

Berdasarkan tabel di atas membentuk pola yang jelas serta titik-titik tersebut tersebar di atas dan di bawah angka nol pada sumbu Y, hal ini menunjukkan bahwa tidak terjadinya heteroskedastisitas. Adapun hasil uji sample paired t-test (uji beda) pada penelitian ini menggunakan SPSS versi 23 yaitu sebagai berikut:

Tabel 4.6

Uji Paired Sample t test

Paired Samples Test

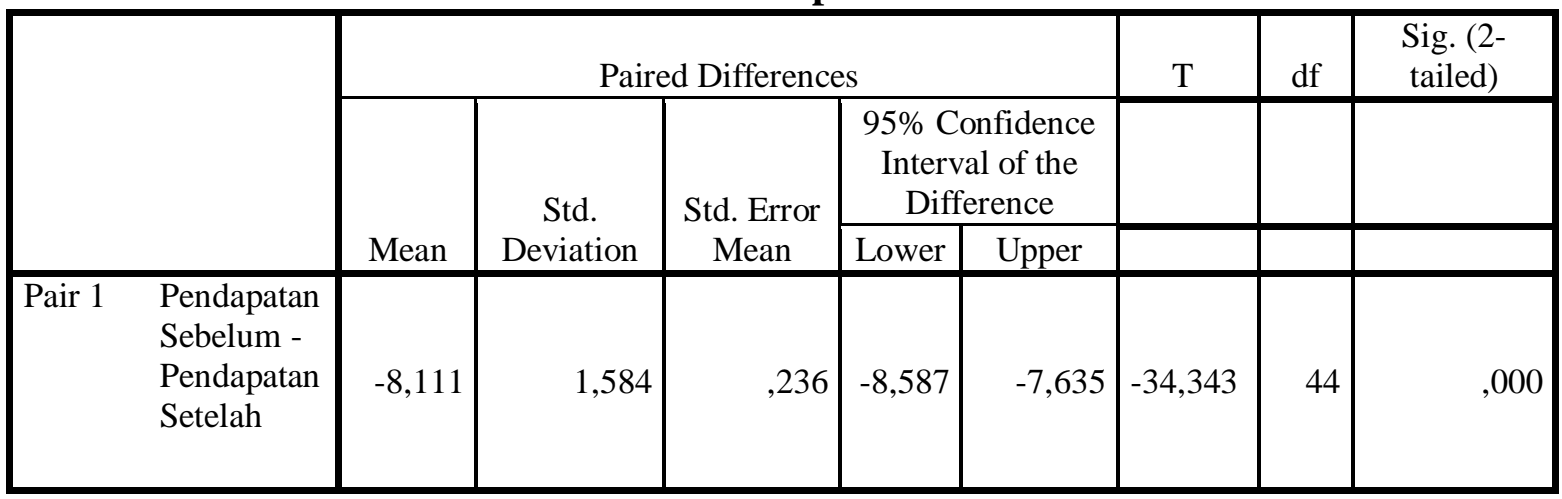

Sumbe : Hasil Penelitian (Hasil Olahan SPSS), 2020

Berdasarkan tabel 4.6 diatas, diketahui nilai sig. (2-tailed) adalah sebesar 0,000 < 0,05, maka Ho ditolak dan Ha diterima. Jadi dapat disimpulkan bahwa ada perbedaan 
rata-rata antara hasil pendapatan sebelum dan setelah mendapatakan pembiayaan murabahah, sehingga pendapatan berpengaruh terhadap pembiayaan murabahah. Dari hasil tabel ini memuat informasi tentang nilai "Mean Paired Differences" adalah sebesar -8,111. Nilai ini menunjukkan selisih antara rata-rata hasil pendapatan sebelum dan sesudah mendapatkan pembiayaan murabahah, dan selisih perbedaan tersebut antara 8,587 sampai dengan $-7,635$.

\section{Pembahasan}

Analisis Perbedaan Pendapatan Sebelum dan Setelah Mendapatkan Pembiayaan Murabahah

Berdasarkan tabel 4.6 diatas, diketahui nilai sig. (2-tailed) adalah sebesar 0,000 < 0,05, maka Ho ditolak dan Ha diterima. Jadi dapat disimpulkan bahwa ada perbedaan rata-rata antara hasil pendapatan sebelum dan setelah mendapatakan pembiayaan murabahah, sehingga pendapatan berpengaruh terhadap pembiayaan murabahah.

Dari penjelasan diatas dapat diketahui bahwa terdapat perbedaan sebelum dan setelah mendapatkan pembiayaan murabahah, dikarenakan pendapatan nasabah terkait dengan kemampuan seseorang dalam mengangsur pembiayaan serta melunasi pembiayaan tersebut. Selain itu juga dapat dijadikan sebagai patokan dalam melakukan negosiasi tingkat margin yang akan ditentukan dalam melakukan pembiayaan. Nasabah Bank Aceh Syariah Capem Krueng Geukueh masih banyak yang berpenghasilan tidak tetap atau rendah, dengan pekerjaan yang mereka miliki itu masih sangat kurang untuk memenuhi kebutuhan sehari-hari. Sehingga mereka membutuhkan tambahan pendapatan dengan cara lain yakni dengan membuka usaha tambahan, dimana modal mereka untuk usaha dapat diambil dengan cara melakukan pembiayaan murabahah di Bank Aceh Syariah Capem Krueng Geukueh.

Setiap peminjam harus jadi penabung, jadi setiap nasabah pembiayaannya secara otomatis menjadi nasabah penabung. Setiap kali nasabah mengangsur pinjaman, nasabah diwajibkan menabung sesuai dengan kemampuan masing-masing. Tabungan ini dapat dijadikan antisipasi jika nasabah menjalankan usaha mengalami kerugian yang berat, sehingga tidak dapat membayar angsurannya. Sebagai alternatifnya tabungan tersebut dapat digunakan untuk menambah angsuran. Jika nasabah tidak mengalami 
hambatan dalam melunasi pinjamannya tabungan tersebut dapat diambil jika angsuran sudah lunas, sehingga nasabah memiliki cadangan untuk menambah modal usaha.

Adapun dampak pembiayaan murabahah untuk pendapatan usaha tidak selalu meningkat bahkan terjadinya penurunan terhadap pendapatan usaha. Diakibatkan pembiayaan murabahah tidak $100 \%$ digunakan untuk modal usaha melainkan banyak digunakan untuk kebutuhan sehari-hari seperti biaya sekolah, belanja dapur dan kebutuhan lainnya. Hal ini lah yang menyebabkan nasabah tidak mampu membayar pinjaman karena pengunaan pinjaman atau talangan dana tidak digunakan sesuai tempatnya.

Pembiayaan murabahah yang diberikan oleh Bank Aceh Syariah Capem Krueng Geukueh berperan terhadap perkembangan usaha yang dapat ditandai dengan adanya peningkatan jumlah pendapatan usaha, keuntungan atau laba usaha, jumlah pembeli atau pelanggan, dan jumlah tenaga kerja. Bertambahnya jumlah pendapatan usaha dapat dikatakan bahwa usaha tersebut mengalami perkembangan, nasabah penerima pembiayaan murabahah mengalami peningkatan pendapatan terhadap usahanya, dikarenakan dengan bertambahnya modal usaha maka nasabah akan berusaha menggunakan modal tersebut dengan optimal, seperti menambah komoditi barang atau memperluas usahanya.

Selain itu bertambahnya jumlah pendapatan usaha akan mempengaruhi jumlah keuntungan atau laba usaha yang akan diperoleh, hal ini dikarenakan jumlah barang yang terjual lebih banyak sehingga dapat meningkatkan jumlah pendapatan usaha yang nantinya akan mempengaruhi kesejahteraan nasabah. 


\section{Simpulan}

Berdasarkan hasil analisis yang dilakukan kepada nasabah terhadap pembiayaan murabahah pada Bank Aceh Syariah Capem Krueng Geukueh maka dapat diambil kesimpulan sebagai berikut Analisis yang dilakukan peneliti terhadap keadaan nasabah bermacam-macam sebelum mendapatkan pembiayaan murabahah. Beberapa nasabah menyatakan bahwa sebelum mendapatkan pembiayaan murabahah usaha yang dijalankan hanya mampu untuk kebutuhan sehari-hari keluarganya seperti konsumsi, oleh karena itu dengan adanya pembiayaan murabahah diharapkan memiliki peran yang penting untuk meningkatkan kesejahteraan nasabah dari keadaan tersebut.

Pembiayaan murabahah yang diberikan Bank Aceh Syariah Capem Kreung Geukueh untuk menambah modal usaha nasabah sangat memberikan manfaat yang baik terhadap peningkatan usaha yang dijalankan oleh nasabah dan meningkatkan taraf hidupnya. Meningkatnya kesejahteraan dapat diukur dengan meningkatnya pendapatan nasabah, meningkatnya tabungan nasabah dan juga kebutuhan nasabah dapat terpenuhi. 


\section{DAFTAR PUSTAKA}

Al-Kaaf Abdullah Zaky, Ekonomi Dalam Persepektif Islam.

Antonio M. Syafi'i. (2000). Bank Syariah dari Teori ke Praktek. Jakarta: Gema Insani Press.

Arikunto, Suharsimi. (2005). Manajemen Penelitian. Jakarta: Rineka Cipta.

Arikunto, Suharsimi, (2006). Prosedur Penelitian Satu Pendekatan Pratik. Jakarta: Rineka Cipta.

Ascarya. (2007). Akad \& Produk Bank Syarah. Jakarta: Raja Grafindo Persada.

Asiyah Binti Nur. (2014). Manajemen Pembiayaan Bank Syariah. Yogyakarta: Teras.

Badan Pusat Statistik. 2000. Indikator Kesejahteraan Rakyat di Indonesia.

Bhuoro, Agung Nugroho. 2005. Strategi Jitu Memilih Metode Statistik Penelitian dengan SPSS. Yogjakarta: ANDI.

Bungin, Burhan. (2006). Metodelogi Penelitian Kuantitatif. Cet. II. Jakarta: Kencana.

Departemen Pendidikan Nasional. (2011). Kamus Besar Indonesia Pusat Bahasa. Jakarta: Gramedia Pustaka Utama.

Fahrudin, Adi. (2012). Pengantar Kesejahteraan Sosial. Bandung: Rafika Aditama.

Gina, Widya dan Jaenal Effendi. (2015). Program Pembiayaan Lembaga Keuangan Mikro Syariah (LKMS) Dalam Peningkatan Kesejahteraan Pelaku Usaha Mikro (Studi Kasus BMT Baitul Karim Bekasi ,http://journal.ipb.ac.id/index.php/jalmuzaraah/article/view/19673

Hakim, Cecep Maskanul. (2011). Belajar Mudah Ekonomi Islam. Tanggerang Selatan: Shahul Media Insani.

Haq, Muhammad Izzul dan Arin Mamlakah Kalamika.nKesejahteraan Nasabah Perbankan Syariah. Yogyakarta Jurnal Program Studi Ilmu Kesejahteraan Sosial. Yogjakarta: UIN Sunan Kalijaga.

Jufri, Reski Amalia. (2017). Pengaruh Pembiayaan Murabahah terhadap Peningkatan Kesejahteraan Usaha Mikro (StudiBMT Asy-Syabaab Kabupaten Pinrang. Skripsi. Sekolah Tinggi Agama Islm Negeri (STAIN) Parepare. http://repository.stainparepare.ac.id/301/1/13.2200.018.pdf.

Kasmir, (2012). Manajemen perbankan. Jakarta: PT. Raja Grafindo Persada.

Khasanah Arinal, (2016). Pengaruh Tingkat Pendidikan, Pendapatan, Motivasi dan Promosi Terhadap Keputusan Menjadi Nasabah Lembaga Keuangan Syariah. Skripsi Institut Agama Islam Negeri (IAIN) Salatiga. 
Kholis Nur, (2015). Kesejahteraan Sosial Di Indonesia Perspektif Ekonomi Islam, Jurnal Akademika.

Kurniawati Maulidah, (2013). Analisis Pengaruh Pembiayaan Murabahah terhadap Kinerja Usaha Nasabah (Studi pada BMT NU Sejahtera Mangkang. Semarang eprints.walisongo.ac.id

Kurniawati Titiek, (2015). Tingkat Kesejahteraan Pengrajin Bambu Di Desa Sendari, Kecamatan Milati, Kabupaten Sleman. Universitas Negeri Yogyakarta

Machfoedz Ircham, dkk, Metode Penelitian, (2005). Cet.V, Yogyakarta: Fitramaya.

Malik Ikhsan Maulana, (2015). Dampak Pembiayaan BMT terhadap kesejahteraan Nasabah Ki Kota Bandung, http://karyailmiah.unisba.ac.id/index.php/ekonomi/article/view/1316

Mansyuri, M. Zainuddin, (2011). Metode Penelitian Pendekatan Praktis dan Aplikatif Edisi Revisi, Bandung: Refika Aditama.

Manurung Adler Haymans, (2008). Modal untuk Bisnis UKM, Jakarta: Kompas Media Nusantara.

Mauludi Ali, (2006). Statistic I: PenelitianEkonomi Islam Dan Sosial, Cet. I, Ciputat: Prima HezaLestari

Najmudin, (2011). Manajeman Keuangan Dan Akuntansi Syar'iyyah Modern Yogyakarta: Andi Offset.

Narbuko Cholid dan H. Abu Acmadi, (2001). Metodologi Penelitian, Jakarta: Bumi Aksara.

Nasikun, (1993). Sistem Sosial Indonesia, Jakarta: Raja Grafindo Persada.

Pareto, Teori Ekonomi Kesejahteraan, (1999). Yogyakarta; Erlangga.

Peraturan Bank Indonesia No. 5/7/PBI/2003 tanggal 19 Mei 2003

Perwataatmadja Karnaen A. dan Hendri Tanjung, (2007). Bank Syariah: Teori Praktik dan Penerapanya, (Jakarta: Celestial Publising.

Pio Andy, Pengertian Jenis dan Langkah-langkah, dalam http://andypio.blogspot.com/2013/10/pengertian-jenis-dan-langkah-langkah.html

Poerwadinata W.J.S, 1996). Pengertian Kesejahteraan Manusia, Bandung: Mizan

Pusat Pengkajian dan Pengembangan Ekonomi Islam, (2008). Ekonomi Islam, Jakarta: Raja Grafindo Persada.

Ridwan Achmad, Keterkaitan tingkat pendidikan dan pendapatan masyarakat dalam http://www.ridwan-belitung.blogspot.com

Rivai Veithzal dan Arviyan Arifin, (2010). Islamic Banking Sebuah Teori, Konsep dan Aplikasi, Jakarta: Bumi Aksara.

Rohmah Siti Nur, (2017). Pengaruh Pembiayaan Murabahah Terhadap Kesejahteraan Nasabah (Studi Kasus Bank Tabungan Pensiunan Nasional Syariah KFO 
ISLAMIC BANKING: Jurnal Pemikiran dan Pengembangan Perbankan Syariah, Volume 6 Nomor 2 Edisi Februari 2021

Cikarang Barat). Skripsi. Sekolah Tinggi Agama Islam (STAI) Pelita Bangsa. http://repository.pelitabangsa.ac.id

Rosni, Analisis Tingkat Kesejahteraan Masyarakat Nelayan Didesa Dahari Selebar Kecamatan Talawi Kabupaten Batu Bara, (Universitas Negeri Medan Fakultas Ilmu Sosial Jurusan Pendidikan Geografi), http://jurnal.unimed.ac.id/2012/index.php/geo

Sidik Priadama dan Saludin Muis, 2009. Metodelogi Penelitian Ekonomi dan Bisnis Yogyakarta: Graha Ilmu.

Sekaran, Uma. (2006). Metode Penelitian Bisnis. Jakarta: Salemba Empat.

Sugiyono, (2007). Metode Penelitian Kuantitatif, Kualitatif Dan R\&D, Bandung: Alfabeta.

Suparmoko, (1991). Pengantar Ekonomika Mikro. Yogyakarta: BPFE

Suriani, (2018). Pelaksanaan Pembiayaan Murabahah Pada SPP PNPM-MP Menurut Tinjauan Ekonomi Syariah, Skripsi IAIN Lhokseumawe.

Sutedi Adrian, (2009). Perbankan Syariah, Jakarta: Galia Indonesia.

Thamrin Abdullah, (2014). Manajemen pemasaran, Jakarta: Raja Grafindo Persada.

Tim Penyusun, Pedoman Teknis Penulisan Proposal dan Skripsi, Sekolah Tinggi Agama Islam Negeri (STAIN) Lhokseumawe, Tahun 2012

Universitas Sumatera Utara, Kesejahteraan Sosial dan Usaha Kesejahteraan Sosial tersedia di http//responsitori.usu.ac.id

Widagdo Ridwan dan Nurul Qomar dengan judul Pengaruh Pembiayaan Murabahah dan Musyarakah Terhadap Perkembangan Usaha Mikro di BMT Gunung Jati https://media.neliti.com/media/publications/261329-program-pembiayaanlembaga-keuangan mikr-6bf3ea8e.pdf.

Winardi,2001. Pengantar Ekonomi, Jakarta: Gahlia Indonesia.

Yuniawati Nia, (2013). Pengaruh Pembiayaan Murabahah Terhadap Peningkatan Pendapatan Usaha Kecil Menegah Studi Kasus Pada Kjks-Bmt El-Syariah Gunung Jati, http://repository.stainparepare.ac.id/301/1/13.2200.018.pdf. 
298 Maulida Mahdalena, Suryani, Ismaulina, ANALISIS PENINGKATAN KESEJAHTERAAN NASABAH...... 